\title{
Supramolecular Principles of Self-Assembly of Pophyrin Nanotubes. 1. Models of SWPNTs Based on 5,10,15,20-Tetrakis(4'-sulfophenyl) porphine Zwitter-Ion
}

\author{
Vladimir B. Sheinin, ${ }^{a}$ Elena V. Bobritskaya, ${ }^{\mathrm{b}}$ Sergey A. Shabunin, ${ }^{\mathrm{a}}$ \\ and Oscar I. Koifman ${ }^{a, b}$ \\ ${ }^{\mathrm{a}}$ G.A. Krestov Institute of Solution Chemistry of Russian Academy of Sciences, 153045 Ivanovo, Russia \\ ' Ivanovo State University of Chemistry and Technology, 153045 Ivanovo, Russia \\ ${ }^{\circledR}$ Corresponding authorE-mail:vbs@isc-ras.ru
}

\begin{abstract}
In this review self-assembling single-walled porphyrin nanotube (SWPNT) models, based on the data of optical spectroscopy, small angle X-ray scattering and cryogenic transmission electron microscopy, are described.l The Short model, suggesting that SWPNT consists of a set of ladder-type "head-to-tail" J-aggregate helices, is demonstrated to be the best to conform to the experimental data. However, this model does not answer fundamental questions on the mechanism and stereometry of tectone binding, on the driving force of J-aggregate twisting into helices and on the nature of bonds between the helices that cannot be solved due to limitations of the used techniques.
\end{abstract}

Key words: Porphyrins, J-aggregates, porphyrin nanotubes, self-assembly.

\section{Супрамолекулярные принципы самосборки порфириновых нанотрубок. 1. Модели ОСПНТ на основе цвиттерионов $5,10,15,20-$ тетракис $(4 '-$ сульфофенил)порфина}

\author{
В. Б. Шейнин, ${ }^{a @}$ Е. В. Бобрицкая, ${ }^{\mathrm{b}}$ С. А. Шабунин, ${ }^{a}$ О. И. Койфман ${ }^{\mathrm{a}, \mathrm{b}}$ \\ ${ }^{\mathrm{a}}$ Институт химии растворов им. Г.А. Крестова РАН, 153045, Иваново, Россия \\ ${ }^{\mathrm{b}}$ Ивановский государственный химико-технологический университет, 153045 Иваново, Россия \\ @E-mail:vbs@isc-ras.ru
}

\begin{abstract}
В настоящем обзоре проведен анализ моделей самособирающейся однослойной порфириновой нанотрубки (ОСПНТ), построенных на основе данных оптической спектроскопии, малоуглового рентгеновского рассеяния и криогенной просвечивающей электронной микроскопии. Показано, что наилучшим образом экспериментальным данным соответствует модель Шорт, которая предполагает, что ОСПНТ состоит из набора супрамолекулярных спиралей на основе Ј-агрегатов «голова кхвосту» ступенчатого типа. Тем не менее, эта модель не дает ответа на основополагающие вопросы о механизме и стереометрии связывания тектонов, о причинах закручивания Ј-агрегатов в спираль, а также о природе связей между спиралями, которые не могут быть решены в рамках этих методов.
\end{abstract}

Ключевые слова: Порфирины, Ј-агрегаты, порфириновые нанотрубки, самосборка. 


\section{Introduction}

Non-covalent self-assembly is a prominent and widespread natural phenomenon which involves molecularlevel encoded formation of ordered dimers and higher oligomers of sometimes extremely complex supramolecular systems. ${ }^{[1]}$ The self-assembly strategy utilized by natural compounds is based on cooperative intermolecular interactions, it became a basis for a biomimetic approach towards new materials via "bottom-up" technology. In the past decade, researchers' attention towards studies of selfassembly processes has been exponentially increasing, as understanding this strategy is greatly promising for the design of various functional nano-materials such as molecular switches, luminescent probes, photonic bandgaps and catalysts..$^{[2-5]}$ The key to understanding the details of selfassembly processes is to study the interdependencies of the self-assembling aggregates' supramolecular structure and the molecular structure of the tectones. Moreover, study of selfassembly mechanisms and properties of the self-assembling structures is a contribution to understanding the nature of life, as self-assembly is the basis for many intracellular processes. $^{[6]}$

Self-assembly of artificial systems is based on employing tectones - molecules containing extra functional groups which define the program of a particular process. Such molecules can auto-arrange into ordered aggregates via various non-covalent interactions (hydrogen bonding, hydrophobic, electrostatic interactions, etc.), a particular interaction set is defined by their electronic and steric properties. Aggregates of water-soluble derivatives of 5,10,15,20-tetraphenylporphyrin $\left(\mathbf{H}_{2} \mathbf{P}(\mathrm{Ph})_{4}\right)$ can be used as biomimetic models of systems that undergo self-assembly under conditions similar to physiological (Figure 1).

Good solubility of these porphyrins is achieved by ionization of the acidic groups (sodium salts or less often ammonium ones are used) resulting in the formation of the corresponding tetraanions. The most popular specimen is 5,10,15,20-tetrakis(4'-sulfophenyl)porphyn $\left(\mathbf{H}_{2} \mathbf{P}\left(\mathrm{PhSO}_{3} \mathrm{H}\right)_{4}\right)$, which combines fine solubility in water and synthetic availability. By April 2013, over 1200 papers have been published, devoted to studies of $\mathbf{H}_{2} \mathbf{P}\left(\mathrm{PhSO}_{3} \mathrm{H}\right)_{4}$ and its aggregates. ${ }^{[7]}$

The zwitter-ion $\mathbf{H}_{4} \mathbf{P}^{2+}\left(\mathrm{PhSO}_{3}^{-}\right)_{4}$ (Figure 2$)$ is considered to be the tectone for the self-assembly processes of $\mathbf{H}_{2} \mathbf{P}\left(\mathrm{PhSO}_{3} \mathrm{H}\right)_{4}$ based aggregates. It is formed at low $\mathrm{pH}$, when almost synchronous diprotonation of nitrogen atoms of the $\mathbf{H}_{2} \mathbf{P}$ porphyrin platform of the $\mathbf{H}_{2} \mathbf{P}\left(\mathrm{PhSO}_{3}\right)_{4}$ tetraanion occurs (1).

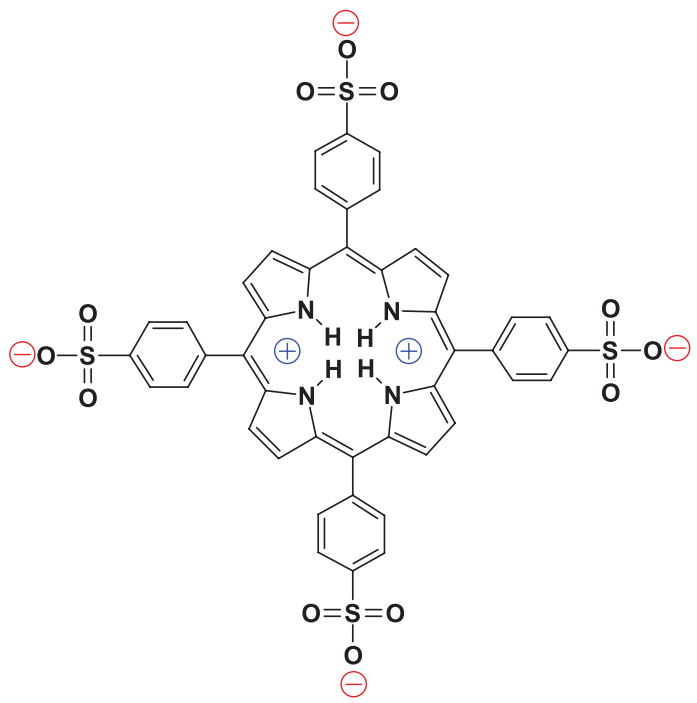

Figure 2. Zwitter-ion $\mathbf{H}_{4} \mathbf{P}^{2+}\left(\mathrm{PhSO}_{3}^{-}\right)_{4}$ as the tectone for SWPNT.

$$
\mathbf{H}_{2} \mathbf{P}\left(\mathrm{PhSO}_{3}^{-}\right)_{4}+2 \mathrm{H}^{+} \stackrel{\boldsymbol{K}_{\mathrm{b} 1} \cdot \boldsymbol{K}_{\mathrm{b} 2}}{\rightleftarrows} \mathbf{H}_{\mathbf{4}} \mathbf{P}^{2+}\left(\mathrm{PhSO}_{3}^{-}\right)_{4}
$$

The $\mathrm{pH}$ range corresponding to the existence of $\mathrm{H}_{4} \mathrm{P}^{2+}\left(\mathrm{PhSO}_{3}^{-}\right)_{4}$ is limited on one part by the diprotonation equilibria of the $\mathbf{H}_{2} \mathbf{P}$ porphyrin platform, which at $298 \mathrm{~K}$ are described by $\lg K_{\mathrm{b} 1}$ and $\lg K_{\mathrm{b} 2}$ values of $4.85 \pm 0.03$ and $4.71 \pm 0.03$, correspondingly, ${ }^{[8]}$ and on the other part - by the protonation equilibria of the sulfonate groups. The protonation constant values of the $\left.\mathbf{H}_{4} \mathbf{P}^{2+}\left(\mathrm{PhSO}_{3}\right)_{4}\right)_{4}$ sulfonate groups are not determined, but can be assumed to be close to the value for phenylsulfonic acid which has a $\lg K_{\mathrm{b}}=0.70(298 \mathrm{~K}){ }^{[9]}$

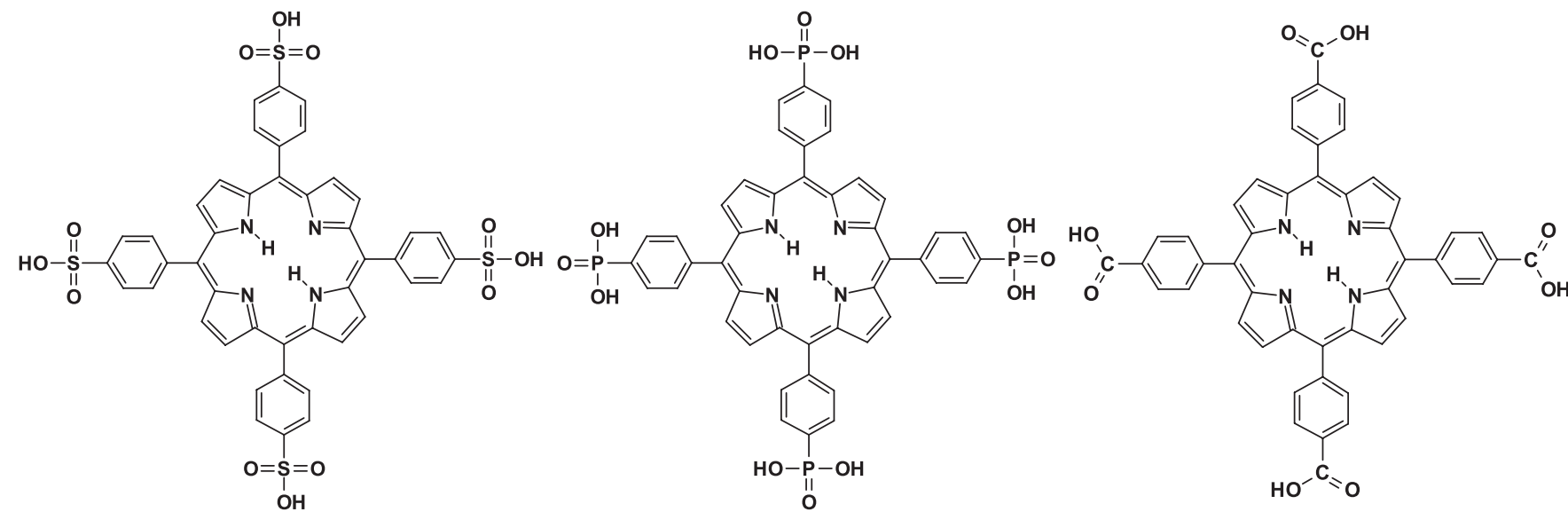

$\mathrm{H}_{2} \mathrm{P}\left(\mathrm{PhSO}_{3} \mathrm{H}\right)_{4}$

$\mathrm{H}_{2} \mathrm{P}\left(\mathrm{PhPO}_{3} \mathrm{H}_{2}\right)_{4}$

$\mathrm{H}_{2} \mathrm{P}\left(\mathrm{PhCO}_{2} \mathrm{H}\right)_{4}$

Figure 1. Water-soluble derivatives of $\mathbf{H}_{2} \mathbf{P}(\mathrm{Ph})_{4}$. 
Ionic self-assembly is considered to be the driving force for the formation of highly ordered aggregates from $\mathbf{H}_{4} \mathbf{P}^{2+}\left(\mathrm{PhSO}_{3}^{-}\right)_{4} \quad$ zwitter-ions, involving intermolecular electrostatic attraction between the positively charged diprotonated $\mathbf{H}_{4} \mathbf{P}^{2+}$ porphyrinic platform and the negatively charged peripheral sulfonate groups of the tectones. ${ }^{[10,11]}$

\section{Properties of SWPNT}

The porphyrin chromophore exhibits high sensitivity to intermolecular interactions, which allows the usage of a wide range of spectroscopic techniques in the studies of self-assembly. Three different aggregate types are proposed to exist for $\mathbf{H}_{4} \mathbf{P}^{2+}\left(\mathrm{PhSO}_{3}^{-}\right)_{4}$, which differ by the assembly pattern: "face-to-face" H-aggregates, "head-to-tail" J-aggregates and "edge-to-face" T-form aggregates (Figure 3). The driving force for the self-assembly of $\mathbf{H}_{4} \mathbf{P}^{2+}\left(\mathrm{PhSO}_{3}{ }^{-}\right)_{4} \mathrm{H}$-aggregates is considered to be $\pi, \pi$-stacking and hydrophobic interactions. Each aggregate type can be identified by electronic absorption spectroscopy.

Convergence of porphyrin chromophores to the distance of dipole-dipole interaction generally leads to quenching of luminescence and to exciton splitting of transition energies in the electronic absorption spectra of the aggregates (Figure 4), which depends on the mutual orientation of transition dipoles and is defined by the tectone binding. ${ }^{[13]}$

Excitation to the lowest energy state in H-aggregates and the highest energy state in J-aggregates is not observed as these transitions are forbidden. As a result, when
$\mathrm{H}$-aggregates are formed, the absorption maxima undergo hypsochromic shifts (compared to the starting monomer) while for J-aggregates the shifts are batochromic. The formation of T-aggregates results in widened or doubletsplit bands. The name of $\mathrm{H}$-aggregates was derived from the Hypsochrimic shift of their absorption maxima compared to the starting monomer, as for J-aggregates - from the first letter of the surname of one of the two pioneer researchers to describe them, E. E. Jelley ${ }^{[14,15]}$ and G. Scheibe. ${ }^{[16,17]}$

The electronic absorption spectra of $\mathbf{H}_{4} \mathbf{P}^{2+}\left(\mathrm{PhSO}_{3}^{-}\right)_{4}$ aggregates (Figure 5) consist of two strong J-bands at $490 \mathrm{~nm}$ and $706 \mathrm{~nm}$, exhibiting a strong hypsochromic shift (about $60 \mathrm{~nm}$ from the starting monomer) and a weak band at 420 $\mathrm{nm}$ with a $14 \mathrm{~nm}$ hypsochromic shift which is attributed to $\mathrm{H}$-aggregates. The presence of both $\mathrm{J}$ - and H-bands implies two types of inter-tectone interactions, "head-to-tail" and "face-to-face". ${ }^{[13]}$

It was demonstrated by SAXS and Cryo-TEM that all aggregates obtained by direct self-assembly of $\mathbf{H}_{4} \mathbf{P}^{2+}\left(\mathrm{PhSO}_{3}^{-}\right)_{4}$ in acidic aqueous media have a morphology of single-walled nanotubes (Figure 6) and no evidence was found for the existence of some other kind of morphology. ${ }^{[7,12,19,20]}$

The diameter of SWPNT varies from 15 to $20 \mathrm{~nm}$, while their length counts dozens to several thousand nm, depending on the conditions of self-assembly. The wall thickness is about $2 \mathrm{~nm}$ which is almost precisely the diagonal size of the $\mathbf{H}_{4} \mathbf{P}^{2+}\left(\mathrm{PhSO}_{3}^{-}\right)_{4}$ tectone.

SWPNT possess supramolecular helical chirality (Figure 7), while the tectones are not optically active.

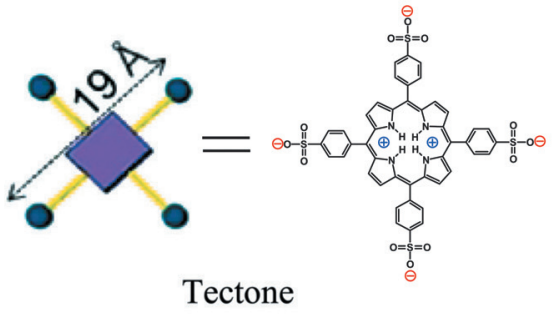

Tectone

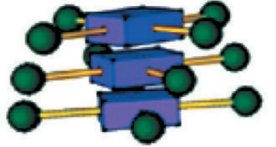

H-aggregate
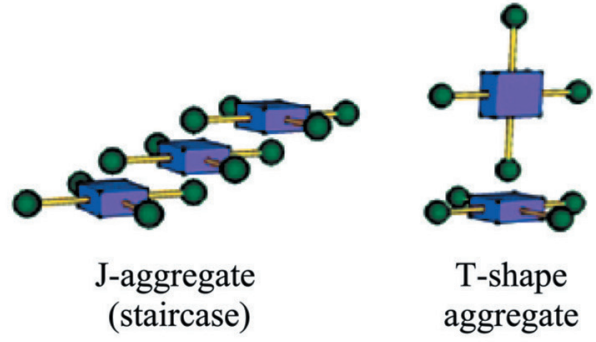

Figure 3. $\mathbf{H}_{4} \mathbf{P}^{2+}\left(\mathrm{PhSO}_{3}{ }^{-}\right)_{4}$ zwitter-ion aggregate types. Adapted with permission from Hollingsworth J.V., Richard A.J., Vicente M.G.H., Russo P.S. Biomacromolecules 2012, 13, 60-72. (C) 2011 American Chemical Society.
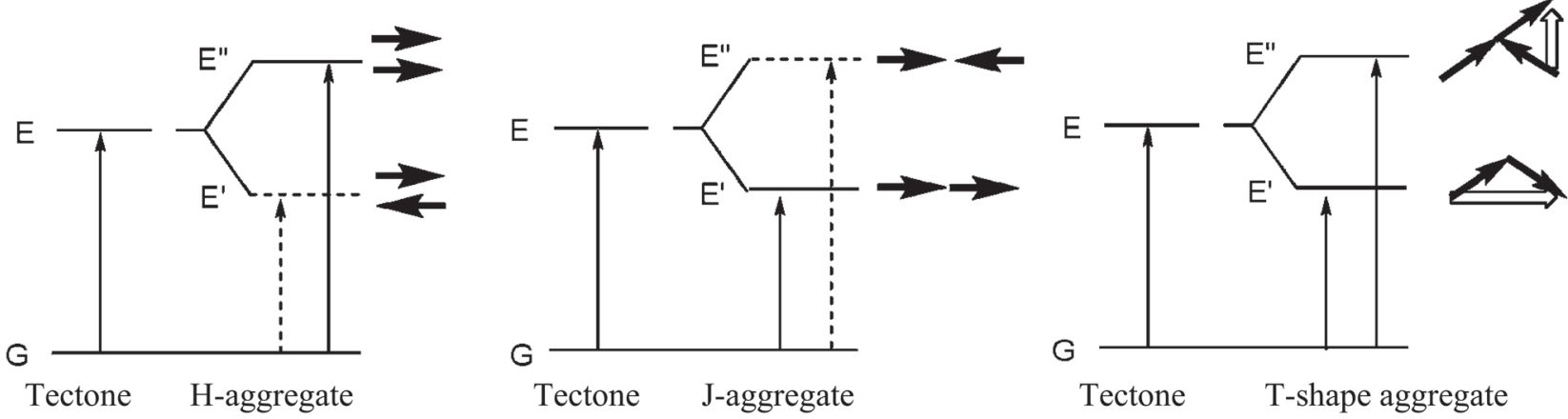

Figure 4. Scheme of the exciton splitting of transition energies in the electronic absorption spectra of various types of porphyrin aggregates. The mutual transition dipole orientations are shown by arrows. Forbidden transitions are shown dashed. Adapted with permission from Satake A., Kobuke Y. Org. Biomol. Chem. 2007, 5, 1679-1691. (C) 2007 The Royal Society of Chemistry. 


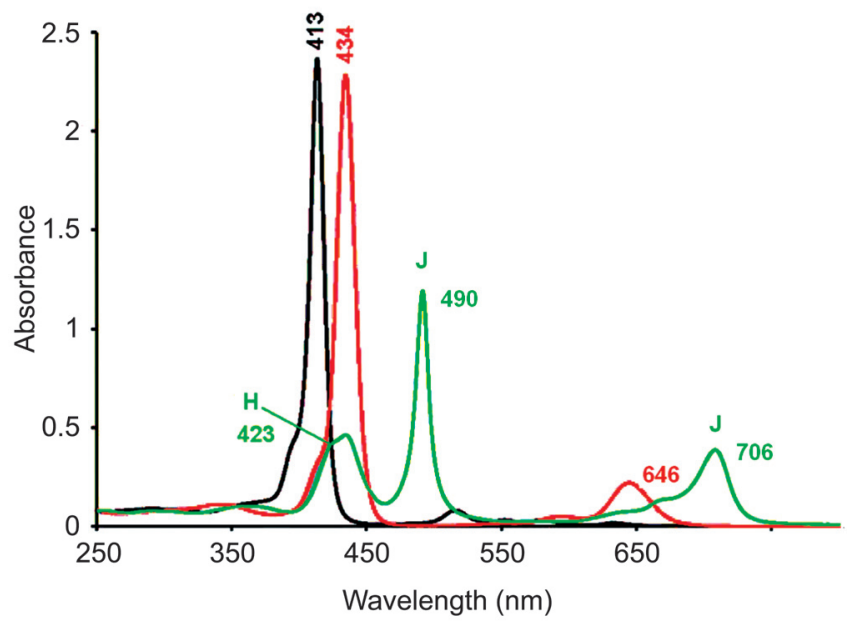

Figure 5. Electronic absorption spectra of aqueous solutions $\left(5 \cdot 10^{-6} \mathrm{~mol} / \mathrm{L},(\ell=1 \mathrm{~cm})\right.$ of $\mathbf{H}_{2} \mathbf{P}\left(\mathrm{PhSO}_{3}^{-}\right)_{4}$ tetraanion at $\mathrm{pH}$ 12.84 (black), $\mathbf{H}_{4} \mathbf{P}^{2+}\left(\mathrm{PhSO}_{3}^{-}\right)_{4}$ zwitter-ion at $\mathrm{pH} 3.25$ (red) and J-aggregates at $\mathrm{pH} 0.125$ (green). The step at $420 \mathrm{~nm}$ is attributed to H-aggregates. Adapted with permission from Friesen B.A., Nishida K.R.A., McHale J.L., Mazur U. J. Phys. Chem. C 2009, 113, 1709-1718. (C) 2009 American Chemical Society.
A non-racemic mixture of SWPNT is formed as the result of self-assembly, one of the two enantiomers is formed in a spontaneous excess. Each enantiomer has a definite signal in CD-spectra. ${ }^{[21]}$ A peculiarity of SWPNT is the dependency of a particular enantiomer's yield on the direction of stirring of the solution.

The chirality of SWPNT presumes that the aggregates they consist of form helices oriented along the longitudinal axis of the tube. Experimental data on the geometry (diameter and wall thickness) and optical properties (J-aggregate absorption bands at 490 and $706 \mathrm{~nm}, \mathrm{H}$-aggregate absorption bands at $320 \mathrm{~nm}$ and chirality) laid the basis for models of supramolecular structure of SWPNT proposed by various authors.

\section{Gandini Model}

Gandini et al. ${ }^{[19]}$ suggested a hollow cylinder model of SWPNT, with the cylinder wall consisting of single-molecular J-aggregate layers in lateral section and $\mathrm{H}$-aggregate heaps in longitudinal section (Figure 8).

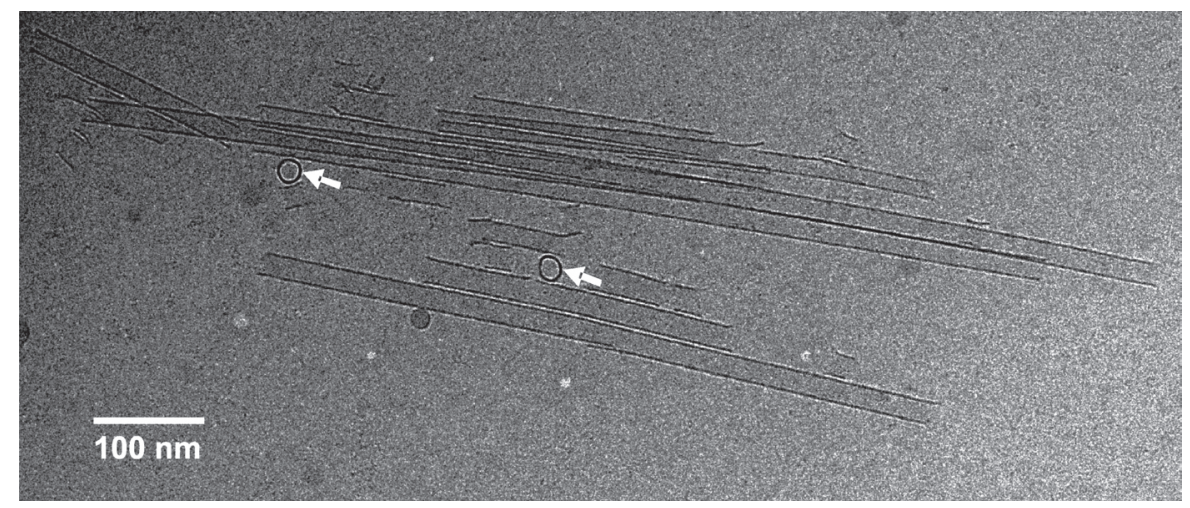

Figure 6. Cryo-EM image of SWPNT. Two fragments of tubules oriented perpendicular to the plane of the image are visible (marked with arrows). Reprinted with permission from Vlaming S.M., Augulis R., Stuart M.C.A., Knoester J., van Loosdrecht P.H.M. J. Phys. Chem. B 2009, 113, 2273-2283. (C) 2009 American Chemical Society.

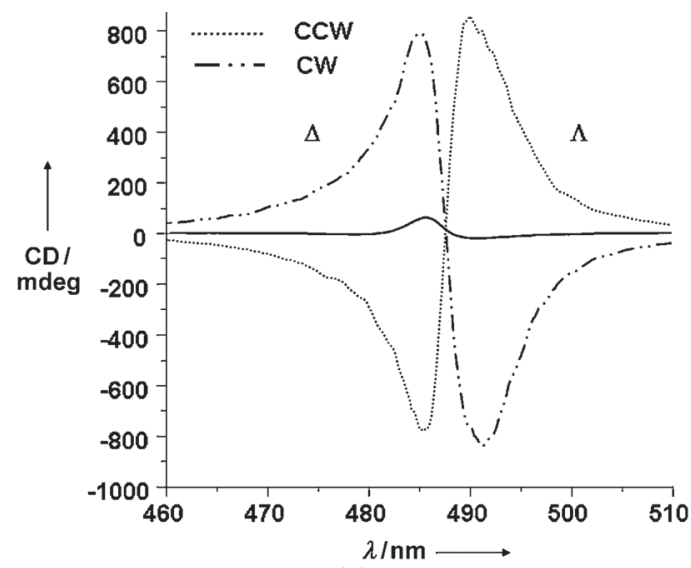

(a)

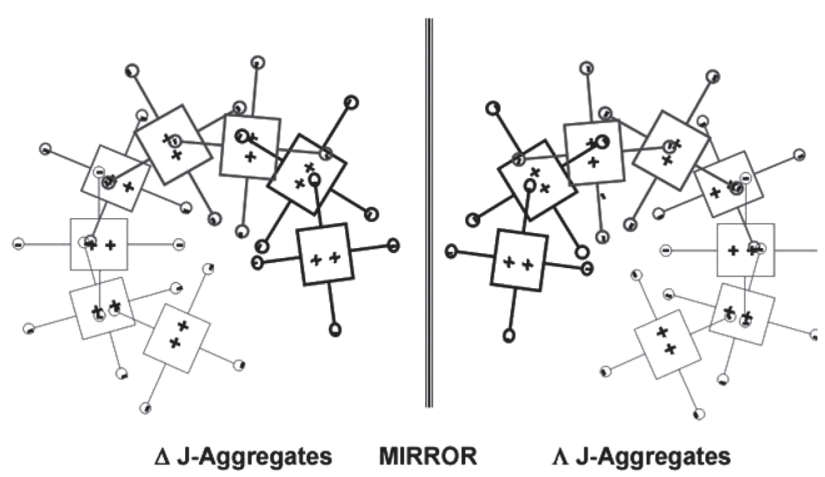

(b)

Figure 7. (a) - Circular dichroism spectra of SWPNT colloidal solution in water $\left(10^{-6} \mathrm{~mol} / \mathrm{L}\right.$ porphyrin, $\left.0.3 \mathrm{~mol} / \mathrm{L} \mathrm{NaCl}, \mathrm{pH} 3\right)$, obtained by clockwise (dot-dashed) and anti-clockwise (dashed). (b) - The proposed structure of chiral J-aggregates. Adapted with permission from Urso A.D., Randazzo R., Lo Faro L., Purrello R. Angew. Chemie, Int. Ed. 2010, 49, 108-112. (C) 2010 Wiley-VCH Verlag GmbH \& Co. KGaA, Weinheim. 


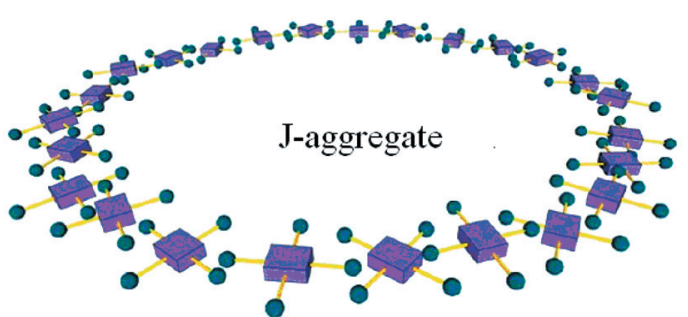

(a)

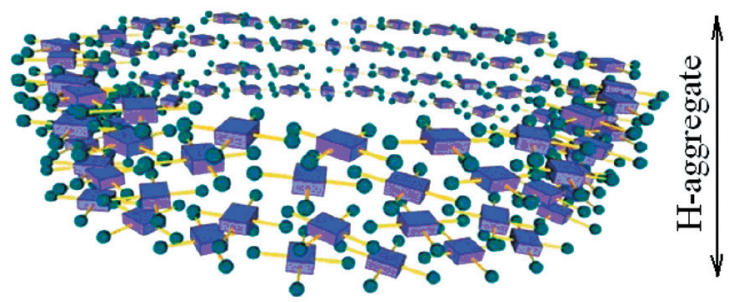

(b)

Figure 8. SWPNT model proposed by Gandini et al. (a) - single layer formed by a circular J-aggregate consisting of 26 tectones arranged "edge-to-edge". (b) - a SWPNT fragment. Adapted with permission from Hollingsworth J.V., Richard A.J., Vicente M.G.H., Russo P.S. Biomacromolecules 2012, 13, 60-72. (C) 2011 American Chemical Society.

The layers have a form of planar rings $1.9 \mathrm{~nm}$ wide. Tectones in the layer are "edge-to-edge"-bound by Coulomb interactions and their number is defined by the outer diameter of the SWPNT. The interlayer distance is $0.3 \mathrm{~nm}$. According to the model, with $16 \mathrm{~nm}$ diameter and $34 \mathrm{~nm}$ length (real SWPNTs, obtained and studied by SAXS technique by the authors) have a thick wall consisting of 113 layers each holding 26 tectones. The Gandini model provides understanding of SWPNTs existence as solid discrete structures ${ }^{[22]}$ and explains the origin of $\mathrm{J}$ - and $\mathrm{H}$-bands in the electronic absorption spectra. However, this model has significant drawbacks that question its credibility. The $\mathrm{H}_{4} \mathrm{P}^{2+}$ porphyrin platform is an anion-molecular receptor, ${ }^{[8,23-27]}$ which has 1,3 -alternate geometry and two binding sites located on the opposite sides from the conventional plane of the porphyrin macrocycle and exists only as part of homogenous and mixed complexes of $\mathbf{H}_{4} \mathbf{P}^{2+}(\mathrm{S})_{2}, \mathbf{H}_{4} \mathbf{P}^{2+}(\mathrm{S})\left(\mathrm{An}^{-}\right), \mathbf{H}_{4} \mathbf{P}^{2+}\left(\mathrm{An}^{-}\right)_{2}$ with solvent molecules and anions (Figure 9).

This circumstance rules out the possibility of formation of tectone $\mathrm{H}$-aggregates from complexes of $\mathbf{H}_{4} \mathbf{P}^{2+}\left(\mathrm{PhSO}_{3}^{-}\right)_{4}$

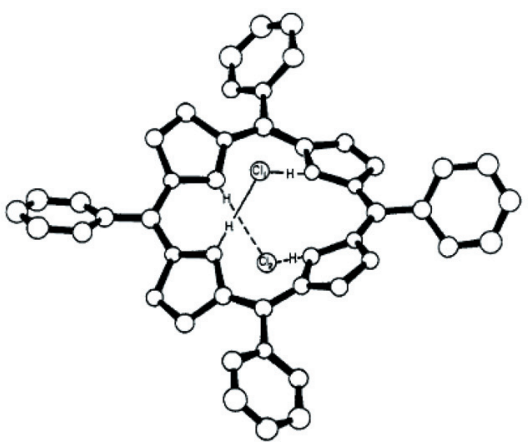

(a)

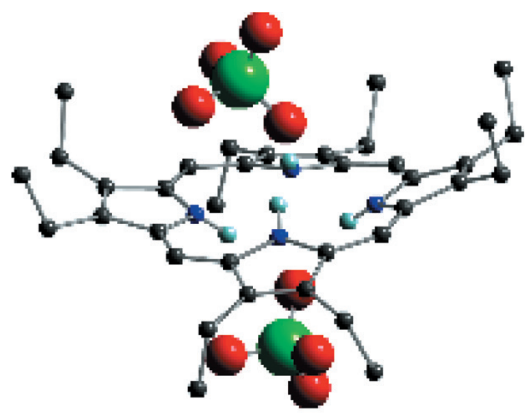

(b)

Figure 9. Structure of diprotonated porphyrins' anionic complexes (a) - $\left[\mathbf{H}_{4} \mathbf{P}^{2+}(\mathrm{Ph})_{4}\right]\left(\mathrm{Cl}^{-}\right)_{2}$ and (b) - $\left[\mathbf{H}_{4} \mathbf{P}^{2+}(\beta-\mathrm{Et})_{8}\right]\left(\mathrm{ClO}_{4}^{-}\right)_{2}$ according to X-ray structure studies. Figure (a) - adapted with permission from Fleischer E.B. Acc. Chem. Res. 1970, 3, 105-112. (C) 1970 American Chemical Society. Figure (b) - adapted with permission from Cheng B., Munro O.Q., Marques H.M., Scheidt W.R. J. Am. Chem. Soc. 1997, 119, 10732-10742. (C) 1997 American Chemical Society.
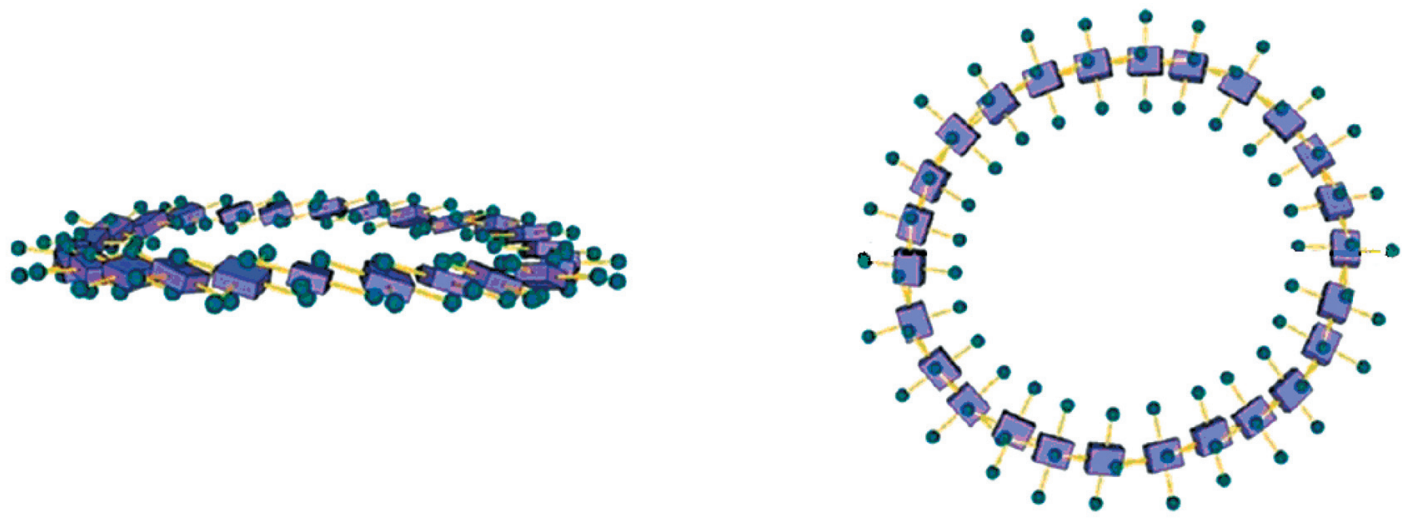

Figure 10. Single SWPNT layer based on ladder-type J-aggregates. Hollingsworth J.V., Richard A.J., Vicente M.G.H., Russo P.S. Biomacromolecules 2012, 13, 60-72. (C) 2011 American Chemical Society. 
with water and/or background anions and as a consequence prevents the self-assembly of SWPNTs from circular J-aggregates. The reasons are similar charges on the deprotonated $\mathbf{H}_{4} \mathbf{P}^{2+}$ porphyrin platforms and the shielding effect of the "guests". Ladder type J-aggregates, formed via binding of sulfonate groups in $\mathbf{H}_{4} \mathbf{P}^{2+}$ sites (Figure 3) are more realistic compared to "edge-to-edge" J-aggregates (Figure 8). But even if we consider the layers to be circular ladder-type J-aggregates ${ }^{[12]}$ (Figure 10), the question still remains of the reason of ring binding inside SWPNTs and the origin of H-bands. Another significant drawback of the SWPNT model based on circular J-aggregates is the absence of helical chirality motive.

\section{Models Identical to Single-Walled Carbon Nanotubes}

Vlaming et al. ${ }^{[20]}$ suggested SWPNT model as a folded sheet of ladder-type porphyrin J-aggregates (Figure 11).

This model explains not only the existence of J-band in SWPNT absorption spectra but chirality as well by an analogy with SWCNT. ${ }^{[28]}$ However, the Vlaming model also has a number of significant drawbacks that question its credibility. While the Gandini model underestimates the interactions of the diprotonated porphyrin platform and the sulfonate groups, the Vlaming model significantly overestimates it, for a single site of $\mathbf{H}_{4} \mathbf{P}^{2+}$ receptor cannot bind two sulfonate groups at a time (Figure 9). Moreover, the Vlaming model contradicts the experimental data that demonstrate not parallel but orthogonal packing of tectones relative to the longitudinal axis of SWPNT, and does not explain the origin of $\mathrm{H}$-band.

Rich and McHale ${ }^{[29]}$ suggested a model of chiral SWPNT with its surface made of 16-dimensional circular ladder-type aggregates, ${ }^{[18]}$ bound together by hydrogen bonds (Figure 12).

The Rich and McHale model conforms to most experimental data but still does not explain the origin of H-band. Weak points of this model (inspired by the structure of SWCNT) are the presumption that 16-dimentional circular J-aggregates exist and the uncertainty of hydrogen bonds between them.

\section{Helical Model by Short}

The above described models were designed on the ground of SAXS and Cryo-TEM data obtained with a resolution of about $0.5 \mathrm{~nm}$ which does not allow the structure of SWPNT to be "seen". Short et al. conducted a Cryo-TEM study with a higher resolution of about $0.2 \mathrm{~nm}$ and were the

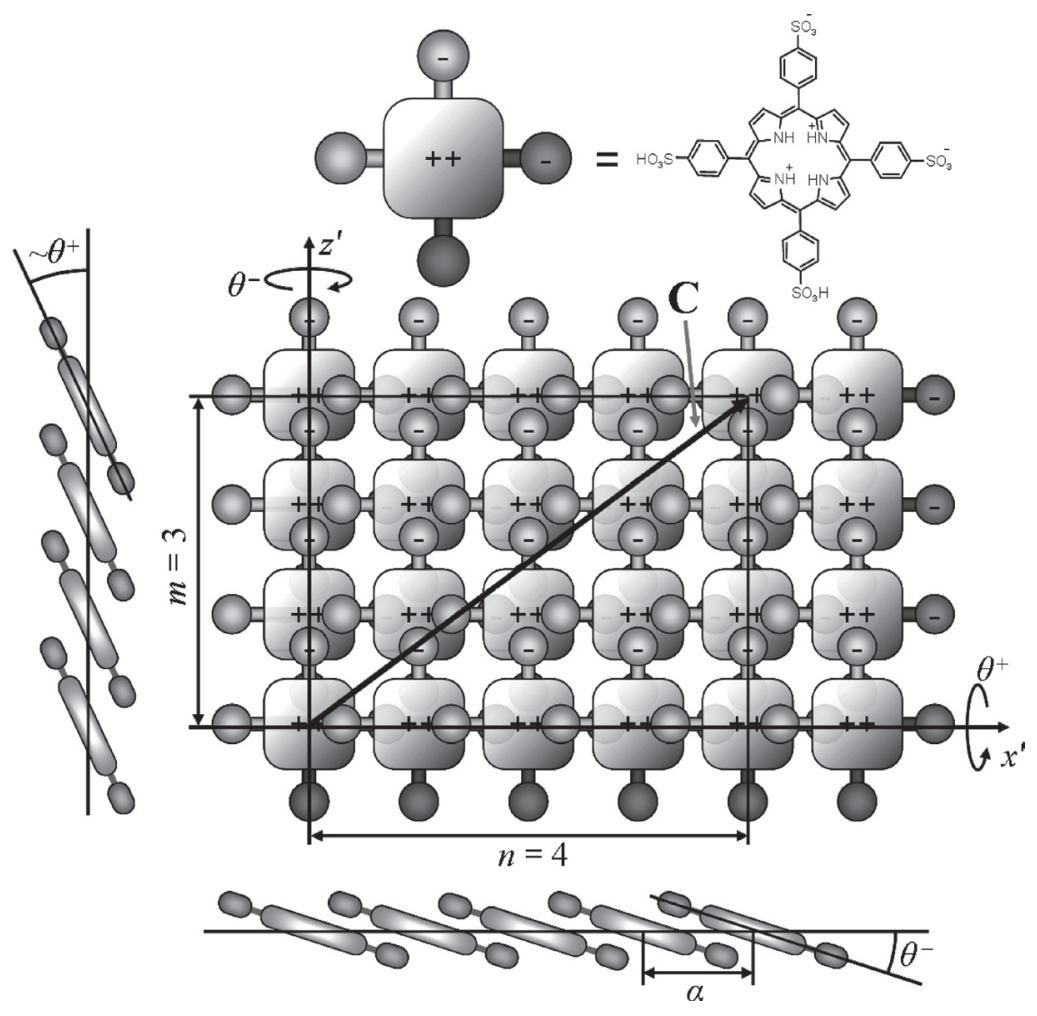

Figure 11. Planar geometry of the aggregate wall. The monomers have been drawn schematically, with charged groups of the monomers indicated. The darker parts lie below the $x^{\prime} z^{\prime}$ plane, while the lighter parts lie above it. The square lattice and the perpendicular axes $\mathbf{x}^{\prime}$ and $\mathbf{z}^{\prime}$, in whose respective directions the lattice vectors $\mathbf{a}_{1}$ and $\mathbf{a}_{2}$ are oriented, have been drawn in the center. Also, an example of a chiral vector $\mathbf{C}=(n, m)=(4,3)$ has been drawn, and to emphasize the tilted orientation of the monomers, the tilting angles $\theta^{+}$and $\theta^{-}$over which each monomer should be rotated have been indicated as well. The lattice parameter $a$ is of the order of $1 \mathrm{~nm}$. The side views on the left and the bottom illustrate the tilted structure of these monomers, with tilting angles $\theta^{+}$and $\theta^{-}$in the order of $15-25^{\circ}$. Reprinted with permission from Vlaming S.M., Augulis R., Stuart M.C.A., Knoester J., van Loosdrecht P.H.M. J. Phys. Chem. B 2009, 113, 2273-2283. C) 2009 American Chemical Society. 
(a)

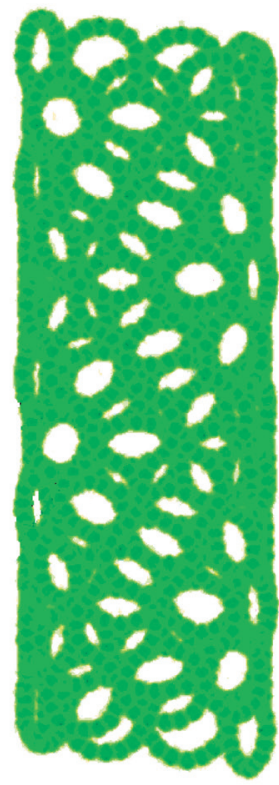

(b)

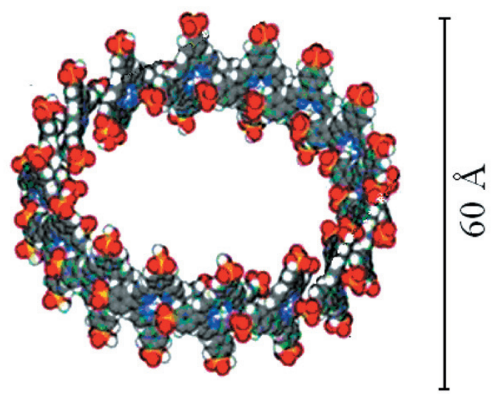

(c)

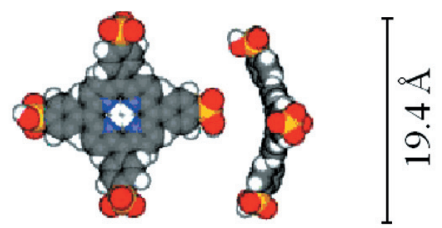

Figure 12. SWPNT model by Rich et al. A chiral SWPNT (a) folded from a sheet consisting of 16-dimentional ladder-type circular J-aggregates (b) based on $\mathbf{H}_{4} \mathbf{P}^{2+}\left(\mathrm{PhSO}_{3}^{-}\right)_{4}$ zwitter-ions (c). Figure (a) adapted with permission from Rich C.C., McHale J.L. Phys. Chem. Chem. Phys. 2012, 14, 2362-2374. (c) 2012 The Royal Society of Chemistry. Figures (b) and (c) adapted with permission from Friesen B.A., Nishida K.A., McHale J.L., Mazur U. J. Phys. Chem. C 2009, 113, 1709-1718. (c) 2009 American Chemical Society.

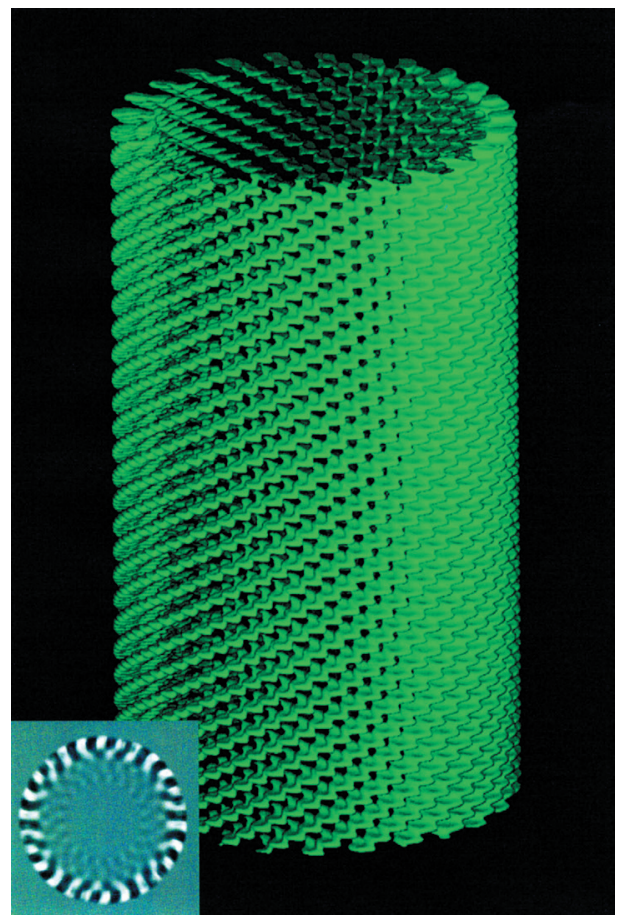

Figure 13. 3D reconstruction of SWPNT from Cryo-TEM data with $0.2 \mathrm{~nm}$ resolution. The insert shows the beginning of 26 helices. The outer diameter is $16 \mathrm{~nm}$, the wall thickness is $2 \mathrm{~nm}$, the tectone angular offset is $5^{\circ}$ and the J-aggregate step height is $0.36 \mathrm{~nm}$. Adapted with permission from Short J.M., Berriman J.A., Kubel C., El-Hachemi Z., Naubron J.-V., Balaban T.S. ChemPhysChem 2013, 14, 3209-3214. (C) 2013 The Authors. Published by Wiley-VCH Verlag GmbH\&Co. KGaA, Weinheim. first to demonstrate the nanotubes to possess helical structure. ${ }^{[7]}$ Based on their experiments, they proposed a SWPNT model which is formed by 26 ladder-type J-aggregate helices, $16 \mathrm{~nm}$ in diameter (Figure 13). Obviously, the Short model is the best match for experimental data on geometry and optical properties of SWPNT that are used as modelling criteria, however it, as well as the previously described models, does not answer the main question about the nature of forces that bind the helices together. As it was mentioned above, the suggestion that $\mathrm{H}$-aggregates play a binding role (based on the interpretation of the $320 \mathrm{~nm}$ absorption band), contradicts the properties of the $\mathbf{H}_{4} \mathbf{P}^{2+}$ diprotonated porphyrin platform, which is an anion receptor. Figure 14 shows the structure of a SWPNT wall which conforms with the Short theory, re-drawn taking into account the sulfonate groups, that prevent $\mathrm{H}$-aggregates from being formed.

\section{Conclusions}

Experimental data obtained by SAXS and CryoTEM demonstrates that aggregates based on $5,10,15,20-$ tetrakis(4'-sulfophenyl)porphine have a morphology of thick single-walled nanotubes with about $2 \mathrm{~nm}$ wall thickness and diameter from 15 to $20 \mathrm{~nm}$, dozens to thousands $\mathrm{nm}$ in length, depending on the conditions of self-assembly. The low resolution of these techniques does not allow to study the molecular-level structure of SWPNT, which resulted in design of models involving the data from optical spectroscopy that point out SWPNT to possess helical supramolecular chirality and to be constructed from J- and H-type aggregates. Short's theory the is the best to conform to experimental data. It presumes that SWPNT consists of a set of supramolecular 


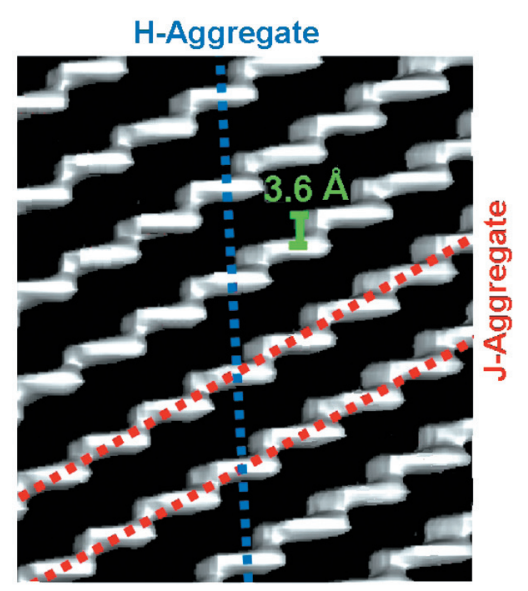

(a)

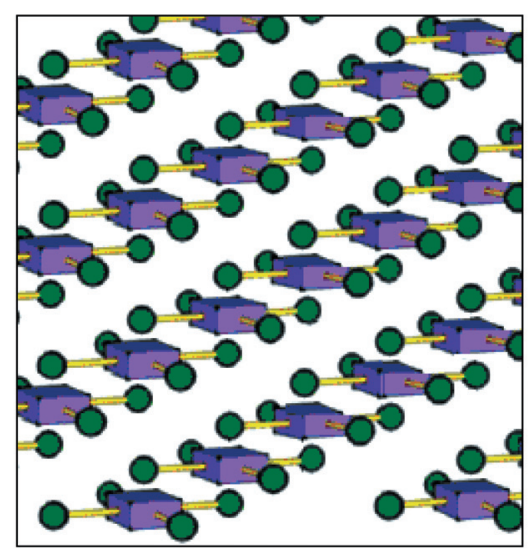

(b)

Figure 14. Helical SWPNT wall structure (a) - according to the Short model, and (b) - re-drawn taking the sulfonate groups into account. It is clear that the binding sulfonate groups hinder the formation of H-aggregates. Figure (a) adapted with permission from Short J.M., Berriman J.A., Kubel C., El-Hachemi Z., Naubron J.-V., Balaban T.S. ChemPhysChem 2013, 14, 3209-3214. (C) 2013 The Authors. Published by Wiley-VCH Verlag GmbH\&Co. KGaA, Weinheim.

helices constructed from ladder-type J-aggregates with a "head-to-tail" pattern. However, this model does not reveal fundamental information on the mechanism and stereometry of tectone binding, on the driving force for the twisting of J-aggregates into a helix, and on the nature of the bonds between the separate helices that form the thick wall of SWPNT. One of the further SWPNT research trends that can afford answers for the questions is molecular modelling utilizing modern techniques of computational chemistry.

Acknowledgments. Financial support by Russian Foundation for Basic Research (V. Sheinin, Project 14-03-90018 Бел_а), Grant of President of Russian Federation (E. Bobritskaya, MK-5844.2013.3), Grant of President of Russian Federation for support of leading scientific schools (HШ-6245.2014.3).

\section{References}

1. Bromley E.H.C., Channon K., Moutevelis E., Woolfson D.N. Peptide and Protein Building Blocks for Synthetic Biology: from Programming Biomolecules to Self-Organized Biomolecular Systems. ACS Chem. Biol. 2008, 3, 38-50.

2. Fendler J.H. Chemical Self-Assembly for Electronic Applications. Chem. Mater. 2001, 13, 3196-3210.

3. Sun S. Recent Advances in Chemical Synthesis, Self-Assembly, and Applications of FePt Nanoparticles. Adv. Mater. 2006, 18, 393-403.

4. Pelesko J.A. Self-Assembly. Taylor \& Francis Group, LLC, 2007, 299 p.

5. Bensaude-Vincent B. Self-Assembly, Self-Organization: Nanotechnology and Vitalism. NanoEthics 2009, 3, 31-42.

6. Whitesides G.M., Grzybowski B. Self-Assembly at All Scales. Science 2002, 295, 2418-2421.

7. Short J.M., Berriman J.A., Kubel C., El-Hachemi Z., Naubron J.-V., Balaban T.S. Electron Cryo-Microscopy of TPPS· $2 \mathrm{HCl}$ Tubes Reveals a Helical Organisation Explaining the Origin of their Chirality. ChemPhysChem 2013, 14, 3209-3214.

8. Sheinin V.B., Shabunin S.A., Bobritskaya E.V., Koifman O.I. Protonation of 5,10,15,20-Tetrakis(4-sulfonatophenyl)- porphine in Water. Macroheterocycles 2011, 4, 80-84.

9. Marushkin S.A., Ph.D. thesis, 1995, Ivanovo, ISUCT.

10. De Napoli M., Nardis S., Paolesse R., Vicente M.G.H., Lauceri R., Purrello R. Hierarchical Porphyrin Self-Assembly in Aqueous Solution. J. Am. Chem. Soc. 2004, 126, 5934-5935.

11. Andrade S.M., Costa S.M.B. Ordered Self-Assembly of Protonated Porphyrin Induced by the Aqueous Environment of Biomimetic Systems. Ann. N. Y. Acad. Sci. 2008, 1130, 305313.

12. Hollingsworth J.V., Richard A.J., Vicente M.G.H., Russo P.S. Characterization of the Self-Assembly of mesoTetra(4sulfonatophenyl)Porphyrin $\left(\mathrm{H}_{2} \mathrm{TPPS}^{4-}\right)$ in Aqueous Solutions. Biomacromolecules 2012, 13, 60-72.

13. Satake A., Kobuke Y. Artificial Photosynthetic Systems: Assemblies of Slipped Cofacial Porphyrins and Phthalocyanines Showing Strong Electronic Coupling. Org. Biomol. Chem. 2007, 5, 1679-1691.

14. Jelley E.E. Spectral Absortion and Fluorescence of Dyes in the Molecular State. Nature 1936, 138, 1009.

15. Jelley E.E. Molecular, Nematic and Crystal States of 1,1Diethyl-c-cyaninechloride. Nature 1937, 139, 631.

16. Scheibe G. ÜberdieVeränderlichkeit des Absorptionsspektrums einiger Sensibilisierungsfarbstoffe und deren Ursache. Angew. Chem. 1936, 49, 563.

17. Scheibe G. Über die Veränderlichkeit der Absorptionsspektren in Lösungen und die Nebenvalenzen als ihre Ursache. Angew. Chem. 1937, 50, 212.

18. Friesen B.A., Nishida K.R.A., McHale J.L., Mazur U. New Nanoscale Insights into the Internal Structure of Tetrakis(4sulfonatophenyl) Porphyrin Nanorods. J. Phys. Chem. C 2009, 113, 1709-1718.

19. Gandini S.C.M., Gelamo E.L., Itri R., Tabak M. Small Angle X-Ray Scattering Study of Meso-Tetrakis (4-Sulfonatophenyl) Porphyrin in Aqueous Solution: A Self-Aggregation Model. Biophys. J. 2003, 85, 1259-1268.

20. Vlaming S.M., Augulis R., Stuart M.C.A., Knoester J., van Loosdrecht P.H.M. Exciton Spectra and the Microscopic Structure of Self-Assembled Porphyrin Nanotubes. J. Phys. Chem. B 2009, 113, 2273-2283.

21. Urso A.D., Randazzo R., Lo Faro L., Purrello R. Vortexes and Nanoscale Chirality. Angew. Chem. Int. Ed. 2010, 49, 108112. 
22. Medforth C.J., Song Y., Wang Z., Jacobsen J.L., Martin K.E., Shelnutt J.A. Self-Assembled Porphyrin Nanostructures. Chem. Commun. 2009, 7261-7277.

23. Sheinin V.B., Simonova O.R., Ratkova E.L. Effect of $\mathrm{pH}$ on Formation of Metalloporphyrins. Macroheterocycles 2008, 1, 72-78.

24. Sheinin V.B., Ratkova E.L., Mamardashvili N.Zh. pHDependent Porphyrin Based Receptor for Bromide-Ions Selective Binding. J. Porphyrins Phthalocyanines 2008, 12, 1211-1219.

25. Sheinin V.B., Shabunin S.A., Bobritskaya E.V., Ageeva T.A., Koifman O.I. Protonation Equilibriums of Porphine, 5,10, 15,20-Tetraphenylporphine, 5,10,15,20-Tetrakis(4'-sulfona- tophenyl)porphine in Methanol. Macroheterocycles 2012, 5 , 252-259.

26. Fleischer E.B. The Structure of Porphyrins and Metalloporphyrins. Acc. Chem. Res. 1970, 3, 105-112.

27. Cheng B., Munro O.Q., Marques H.M., Scheidt W.R. An Analysis of Porphyrin Molecular Flexibility-Use of Porphyrin Diacids. J. Am. Chem. Soc. 1997, 119, 10732-10742.

28. Harris P. Carbon Nanotubes and Related Structures. New Materials for the $21^{\text {st }}$ Century. Cambridge University Press, 1999.

29. Rich C.C., McHale J.L. Influence of Hydrogen Bonding on Excitonic Coupling and Hierarchal Structure of a Light-Harvesting Porphyrin Aggregate. Phys. Chem. Chem. Phys. 2012, 14, 2362-2374.

Received 09.10.2014

Accepted 25.10.2014 